\title{
Effects of extraction methods on the flavonoid and phenolic contents and anti-aging properties of Rhyncholaeliocattleya Haw Yuan Beauty extracts
}

\author{
Rittipun Rungruang $^{\mathrm{a}, *}$, Tasanee Panichakul ${ }^{\mathrm{a}}$, Wittawat Rattanathavorn ${ }^{\mathrm{a}}$, Nattapon Kaisangsri ${ }^{\mathrm{b}}$, \\ Orapin Kerdchoechuen ${ }^{c}$, Natta Laohakunjit ${ }^{c}$, Louis Kuoping Chao ${ }^{d}$ \\ a Department of Cosmetic Science, Faculty of Science and Technology, Suan Dusit University, \\ Bangkok 10700 Thailand \\ b Pilot Plant Development and Training Institute, King Mongkut's University of Technology Thonburi \\ (Bangkhuntein Campus), Bangkok 10150 Thailand \\ c Division of Biochemical Technology, School of Bioresources and Technology, King Mongkut's University \\ of Technology Thonburi (Bangkhuntein Campus), Bangkok 10150 Thailand \\ ${ }^{d}$ Department of Cosmeceutics, China Medical University, Taichung 40402 Taiwan
}

*Corresponding author, e-mail: rittipun_run@dusit.ac.th

Received 25 Nov 2020

Accepted 24 Aug 2021

\begin{abstract}
Rhyncholaeliocattleya Haw Yuan Beauty (Rlc. Haw Yuan Beauty) is a traditional orchid in tropical and subtropical Asian regions, which has attracted attention for its fragrant flowers with diverse colors. This study aimed to investigate the effects of different extraction methods on the phenolic profile, total flavonoid and cyanidin-3-Oglucoside contents, and anti-aging properties of Rlc. Haw Yuan Beauty crude extracts. The crude extracts were obtained using solvent, ultrasonic, and supercritical carbon dioxide fluid extraction methods. The major phenolic compounds including gallic, chlorogenic, and caffeic acids were present in all the extracts. The extract obtained with solvent extraction showed the highest total flavonoid content, whereas that obtained with supercritical fluid extraction yielded the highest cyanidin-3-O-glucoside content. Additionally, the different extraction methods had a significant influence on the antioxidant, anti-elastase, and anti-collagenase activities $(p<0.05)$ of Rlc. Haw Yuan Beauty extracts. The crude extracts derived from the ultrasonic and supercritical carbon dioxide fluid extraction methods were not cytotoxic to human skin fibroblasts at any of the tested concentrations (31-500 $\mu \mathrm{g} / \mathrm{ml})$. Thus, the crude extracts from Rlc. Haw Yuan Beauty could be a safe and active ingredient in the production of skincare products in the cosmetic industry for human use.
\end{abstract}

KEYWORDS: phenolic compounds, cyanidin-3-O-glucoside, Rhyncholaeliocattleya Haw Yuan Beauty, antioxidant activity, anti-aging

\section{INTRODUCTION}

Orchidaceae is the largest family of flowering plants with over 850 genera and 35000 species [1]. Rlc. Haw Yuan Beauty is a commercially viable orchid derived from Taiwan, a hybrid cross of Rlc. Haw Yuan Moon and C. Mari's Song and is a valuable ornamental plant because of the diverse colors of its flowers. This orchid blooms with terrace-shaped, magenta colored flowers with a strong floral scent, approximately 3 times per year. Phytochemicals have bioactivities towards animal biochemistry and metabolism and are widely studied for their health benefits. Alkaloids, flavonoids, carotenoids, anthocyanins, and sterols are the major phytochemicals [2]. The consumption of orchids rich in an- tioxidants can prevent degenerative and chronic diseases [3]. Previous studies revealed that Rlc. Beauty Girl 'KOVA' (KOVA) flowers contained flavonoids, anthocyanins, $\alpha$-carotene, and lutein [4], and had high antioxidant activity. Cymbidium spp. contains phenanthrenes while Dendrobium crepidatum extract was found to possess antimicrobial activity with an $\mathrm{IC}_{50}$ of $73.90 \mu \mathrm{g} / \mathrm{ml}$ [5]. The above bioactive compounds have been isolated from orchids and have been used in the cosmetic, pharmaceutical, and food industries for their antibacterial and antioxidative properties [6]. Tadokoro et al [7] reported that skincare products containing $5 \%$ orchid extract from Brasso cattleya showed skinwhitening effects on melasma in women. Moreover, Vanda coerulea Griff. ex Lindl. and V. teres 
(Roxb.) Lindl. extracts have shown anti-aging and skin-moisturizing potential [8]. The content of orchid phenolic compounds and flavonoids is affected by several factors including ecological conditions, harvest time, and extraction techniques. Several techniques including conventional and innovative methods could be used to isolate bioactive compounds from plants using various organic solvents such as ethanol, methanol, and acetone $[9,10]$. In a previous study, the ethanol extract of Commelina nudiflora L. showed high antioxidant and antimicrobial activities [11]. In addition, the 70\% ethanol extract of Himantoglossum robertianum contained flavones and flavan-3-ols showing antioxidant and elastase and collagenase inhibitory activities [12]. However, solvent extraction cannot extract active ingredients in their entirety. Therefore, ultrasonic and supercritical fluid extraction methods have been applied to improve the extraction efficiency. The flavone C-glycosides including vicenin-2, vicenin3 , schaftoside, vitexin, and isovitexin were found in Cymbidium kanran after ultrasound-assisted extraction with $70 \%$ methanol as a co-solvent [13]. Additionally, miquelianin was detected in Cuphea glutinosa extracts using ultrasound-assisted extraction with $38 \%$ ethanol as a co-solvent [14]. However, solvent waste reduction and excess energy consumption for solvent removal are concerns limiting the applicability of this method; thus, supercritical carbon dioxide has been considered useful for bioactive extraction [15]. According to GiménezRota et al [16], the ethanolic extracts of Lavandula luisier using the supercritical method contained an adequate amount of rosmarinic acid. The supercritical extraction conditions used were $35 \mathrm{MPa}$ pressure at $45^{\circ} \mathrm{C}$ for $150 \mathrm{~min}$, which have been applied to obtain vasilic acid extract from vanilla pods. Despite the potential of Rlc. Haw Yuan Beauty orchid, little information is available on the antioxidant and cytotoxic activities of its flavonoid and phenol contents, which are the major compounds found in orchids [17]. This study aimed to investigate the effects of different extraction methods on the phenolic content, antioxidant activities, cytotoxicity, and anti-aging properties of the crude extracts of Rlc. Haw Yuan Beauty.

\section{MATERIALS AND METHODS}

\section{Materials}

Rlc. Haw Yuan Beauty flowers were collected in January from Bangkok Flowers Centre Co., Ltd., Thailand. The orchid flowers were air-dried, ground, and stored in a refrigerator until required for experimental analyses.

\section{Solvent extraction (SE)}

Rlc. Haw Yuan Beauty flowers were ground using a mortar, and $100 \mathrm{~g}$ of the powder was treated with $400 \mathrm{ml}$ of $70 \% \mathrm{EtOH}$, according to the method of Molnar et al [18] with some modifications. Ethanolic extraction was performed using a shaker at $120 \mathrm{rpm}$ and $25 \pm 2{ }^{\circ} \mathrm{C}$ for $24 \mathrm{~h}$. After the extraction, the mixture was filtered through Whatman No. 1 filter paper. The supernatant was removed using a rotary evaporator at $50^{\circ} \mathrm{C}, 150 \mathrm{rpm}$. The percentage yield of the crude extract was then calculated based on the dry weight using the formula:

$$
\% \text { Yield of extract }=\frac{\text { Weight of extract }(\mathrm{g})}{\text { Weight of dried plant }(\mathrm{g})} \times 100
$$

\section{Ultrasonic-assisted liquid extraction (USE)}

Dried Rlc. Haw Yuan Beauty flowers (100 g) were extracted with $400 \mathrm{ml}$ of $70 \% \mathrm{EtOH}$ and sonicated $(40 \mathrm{kHz})$ for $2 \mathrm{~h}$. Extraction was carried out using an ultrasonic cleaner bath (GT SONIC D-series, Shenzhen, PRC) with a designed ultrasonic power (50$150 \mathrm{~W}$ ) with a sonication time of $2 \mathrm{~h}$ at extraction temperature between $25-35{ }^{\circ} \mathrm{C}$ [19]. The mixture was filtered, and the percentage yield of the crude extract was calculated as described above.

\section{Supercritical fluid extraction (SFE)}

SFE extracts were obtained using a Laboratory Scale SFE (model SFE-500F-2-C50, Thar Technology, Pittsburgh, USA), and $30 \mathrm{~g}$ of the dry flower was loaded into the extraction chamber. Extraction was carried out with $70 \%$ ethanol as a co-solvent at $40^{\circ} \mathrm{C}$ and 200 bar. The total extraction duration was $100 \mathrm{~min}$ with a $\mathrm{CO}_{2}$ flow rate of $10 \mathrm{~g} / \mathrm{min}$. A rotary evaporator was used to remove water from the crude extract at $50^{\circ} \mathrm{C}$ and $150 \mathrm{rpm}$ [20], and the percentage yield of the crude extract was subsequently calculated.

\section{Determination of the total flavonoid content in the extract}

The total flavonoid content in the crude extracts was quantified using the aluminum chloride colorimeter method with some modifications [21]. The crude extract $(30 \mu \mathrm{l}$ of $1 \mathrm{mg} / \mathrm{ml})$ was incubated in a 96-well plate, and a mixture of $\mathrm{NaNO}_{2}(1: 5 \mathrm{w} / \mathrm{v})$ dissolved in $100 \mu \mathrm{l}$ of methanol was added and incubated for $6 \mathrm{~min}$. Subsequently, $15 \mu \mathrm{l}$ of $\mathrm{AlCl}_{3}$ $(1: 10 \mathrm{w} / \mathrm{v})$ was added to the mixture and allowed 
to incubate for 6 min with a final addition of $55 \mu$ l of $1 \mathrm{M} \mathrm{NaOH}$ for $10 \mathrm{~min}$ at room temperature (approximately $25 \pm 2{ }^{\circ} \mathrm{C}$ ). Thereafter, the absorbance of the reaction mixture was measured at $510 \mathrm{~nm}$ using a microplate reader (Biochrom EZ Read 2000, Cambridge, UK). Quercetin was used as a standard flavonoid for the preparation of the calibration curve, and total flavonoid content was reported as quercetin equivalents (mg QE/g extract).

\section{Separation and quantification of cyanidin-3-O-glucoside}

A $100 \mu \mathrm{l}$ sample $(20 \mathrm{mg} / \mathrm{ml})$ was injected into an HPLC apparatus (Agilent Technology Inc., Palo Alto, CA, USA) equipped with an Agilent Eclipse XBD-C18 reverse-phase $(4.6 \mathrm{~mm} \times 150 \mathrm{~mm}, 5 \mu \mathrm{m})$ and a UV-visible diode-array detector. An isocratic method using $0.1 \%$ trifluoroacetic acid in Milli-Q water (solvent A) and acetonitrile (solvent B) at a flow rate of $0.4 \mathrm{ml} / \mathrm{min}$ for $25 \mathrm{~min}$ was used for the chromatographic separation. Peak areas were identified by comparing the retention times with those of cyanidin-3-O-glucoside as an authentic standard. The absorbance was measured at $530 \mathrm{~nm}$.

\section{Determination of phenolic compounds}

Phenolic compounds in the crude extracts were analyzed using HPLC and the C18 reverse-phase column as mentined above. The analysis was carried out using a gradient elution of $0.3 \mathrm{M}$ orthophosphoric acid as solvent A and methanol as solvent $B(60: 40 \mathrm{v} / \mathrm{v})$ at $0 \mathrm{~min}$. This was increased to $100 \% \mathrm{~B}$ from 10 to $15 \mathrm{~min}$ at a flow rate of $1 \mathrm{ml} / \mathrm{min}$, according to Ghasemzadeh et al [21] with some modifications. Subsequently, the ratio was returned to $60 \%$ for $A$ and $40 \%$ for $B$ at $20 \mathrm{~min}$. The calibration curves of the analyzed phenolics were made in triplicate for each standard (gallic acid, chlorogenic acid, caffeic acid, myricetin, luteolin, kaempferol, and apigenin).

\section{Evaluation of the antioxidant activity \\ Reduction of DPPH radicals}

The DPPH $^{\bullet}$ 2,2-Diphenyl-1-(2,4,6-trinitrophenyl) hydrazyl radical scavenging activity was evaluated according to Brand-Williams et al [22]. The crude extract was diluted with ethanol to prepare a dilution of the concentrations $(0.001953-1 \mathrm{mg} / \mathrm{ml})$. An aliquot of $50 \mu \mathrm{l}$ of the sample and $150 \mu \mathrm{l}$ of $0.16 \mathrm{mM}$ DPPH solution in the ethanolic crude extract was mixed in a 96-well plate and incubated in the dark at room temperature for $30 \mathrm{~min}$. The absorbance of the solution was measured at $515 \mathrm{~nm}$, and Lascorbic acid and Trolox were used as controls. The radical scavenging activity was calculated using the following equation:

$$
\% \text { Scavenging }=\frac{\mathrm{A}_{\text {blank }}-\mathrm{A}_{\text {sample }}}{\mathrm{A}_{\text {blank }}} \times 100
$$

where $A_{\text {blank }}$ is the absorbance of the blank and $\mathrm{A}_{\text {sample }}$ is the absorbance of the crude extract. The results were expressed as $\mathrm{IC}_{50}$ values $(\mathrm{mg} / \mathrm{ml})$ (50 $\mathrm{DPPH}^{\bullet}$ scavenging effect concentration).

\section{ABTS (2,2'-azino-bis (3-ethylbenzothiazoline-6-} sulfonic acid) radical scavenging activity

The reaction mixture contained $7 \mathrm{mM} \mathrm{ABTS}^{\bullet+}$ and $2.45 \mathrm{mM}$ potassium persulfate, and the mixture was incubated in the dark at room temperature for 12-16 h. The reaction was monitored at $734 \mathrm{~nm}$ until a stable absorbance of $0.70 \pm 0.05 \mathrm{~nm}$ was obtained [23]. Forty microliters of crude extracts were mixed with $160 \mu \mathrm{l} \mathrm{\textrm {ABSS } ^ { \bullet + }}$ solution, and the absorbance of the resulting solution was measured after $6 \mathrm{~min}$ at $734 \mathrm{~nm}$. The radical scavenging activity was calculated as stated above.

\section{Evaluation of the cytotoxic activity}

The cytotoxic activity of the extracts was determined using the MTT (3-[4,5-dimethylthiazol-2yl]-2,5 diphenyl tetrazolium bromide) assay [24]. Human skin fibroblast ATCC no. CRL 1947 (CCD986SK) was cultured in RPMI 1640 medium with $5 \%$ fetal calf serum and incubated under $5 \% \mathrm{CO}_{2}$ at $37^{\circ} \mathrm{C}$. The cells in the exponential phase were harvested and trypsinized with $0.05 \%$ trypsin-EDTA. A suspension of $2.5 \times 10^{4}$ cells $/ \mathrm{ml}$ of medium was placed into each well of the 96-well microtiter cell culture plate at $200 \mu \mathrm{l} /$ well and incubated for $24 \mathrm{~h}$. Extracts were added within a range of 5 cytotoxic concentrations $(31,62,125,250$, and $500 \mu \mathrm{g} / \mathrm{ml}$ ) and incubated for $72 \mathrm{~h}$. Ten microliters of $5 \mathrm{mg} / \mathrm{ml}$ MTT were added to each well, and the plate was re-incubated for $4 \mathrm{~h}$. Subsequently, the culture medium was removed, and dimethyl sulfoxide $(150 \mu \mathrm{l})$ and glycine buffer $(\mathrm{pH} 10.5$; $25 \mu \mathrm{l})$ were added to the 96 -well plate. The supernatant was gently shaken until the formazan crystals formed were dissolved. Finally, the absorbance was measured using a microplate reader (Thermo Scientific, Waltham, MA, USA) at $540 \mathrm{~nm}$, and the percentage of surviving cells was calculated using the following formula:

$$
\% \text { Survival }=\frac{\mathrm{A}_{\text {sample }}}{\mathrm{A}_{\text {control }}} \times 100
$$

where $A_{\text {sample }}$ is the absorbance of the extract and $A_{\text {control }}$ is the absorbance of the control. 
Table 1 Yield, total flavonoid and cyanidin-3-O-glucoside contents of the crude extracts from Rlc. Haw Yuan Beauty.

\begin{tabular}{lccc}
\hline $\begin{array}{l}\text { Extraction } \\
\text { method }\end{array}$ & \% Yield & $\begin{array}{c}\text { Total flavonoid } \\
\text { (mg QE/g extract) }\end{array}$ & $\begin{array}{c}\text { Cyanidin-3-O- } \\
\text { glucoside } \\
(\mu \mathrm{g} / \mathrm{g} \text { extract })\end{array}$ \\
\hline SE & $2.39 \pm 0.15^{\mathrm{b}}$ & $8.45 \pm 0.009^{\mathrm{a}}$ & $63.63 \pm 0.74^{\mathrm{c}}$ \\
$\mathrm{USE}$ & $4.58 \pm 0.17^{\mathrm{a}}$ & $7.01 \pm 0.006^{\mathrm{b}}$ & $114.69 \pm 1.08^{\mathrm{b}}$ \\
SFE & $1.36 \pm 0.07^{\mathrm{c}}$ & $6.68 \pm 0.007^{\mathrm{c}}$ & $43599.77 \pm 10.23^{\mathrm{a}}$ \\
\hline \multicolumn{3}{c}{ a,b,c Different letters represent significant difference $(p<$} \\
\multicolumn{3}{c}{ 0.05). Values are expressed as mean $\pm \mathrm{SD}(N=3)}$.
\end{tabular}

\section{Collagenase inhibitory activity}

The collagenase inhibitory activity was evaluated in vitro with fluorometric assays, according to Pientaweeratch et al [25]. The activity was quantified using the EnzChek ${ }^{\circledR}$ Gelatinase/Collagenase assay Kit. In a 96-well plate, $20 \mu 1$ of crude extract $(1 \mathrm{mg} / \mathrm{ml})$ and $100 \mu \mathrm{l}$ of collagenase from Clostridium histolyticum was added per well with $20 \mu \mathrm{l}$ of DQ ${ }^{\mathrm{TM}}$ collagen 1 (MMP-1) and $\mathrm{DQ}^{\mathrm{TM}}$ gelatin (MMP-2). The mixture was incubated at $25^{\circ} \mathrm{C}$ for $90 \mathrm{~min}$ in the dark. The fluorescence intensity was measured at $485 \mathrm{~nm}$ (excitation wavelength) and $538 \mathrm{~nm}$ (emission wavelength), while epigallocatechin gallate (EGCG) was used as a positive control.

\section{Elastase inhibitory activity}

This assay was performed as previously described by Kim et al [26] with slight modifications. Enzymatic inhibition was determined by measuring the intensity of porcine pancreatic elastase (PEE.C.3.4.21.36) with $1.6 \mathrm{mM} \mathrm{N}$-succinyl-Ala-Ala-Ala$p$-nitroanilide as a substrate. For pre-incubation, $20 \mu \mathrm{l}$ of crude extract and porcine pancreatic elastase were added to 96-well plates and incubated at $25^{\circ} \mathrm{C}$ for $15 \mathrm{~min}$. Finally, adjust the total volume to $250 \mu \mathrm{l}$ with $1.6 \mathrm{mM} \mathrm{N}$-Succinyl-Ala-Ala-Ala- $p$ nitroanilide and incubated at $25^{\circ} \mathrm{C}$. The absorbance was measured at 381 and $402 \mathrm{~nm}$ using a microplate reader, and EGCG was used as a standard.

\section{Statistical analysis}

Data were analyzed using the SAS version 9 software (SAS Institute; USA). Statistical analysis was performed using Analysis of Variance (ANOVA), and all the results were expressed as the mean \pm standard deviation (SD). Duncan's Multiple Range Test was used to determine significant differences between means $(p<0.05)$.

\section{RESULTS AND DISCUSSION}

\section{Extraction yield}

The extraction yield obtained by 3 different extraction procedures (SE, USE, and SFE) is summarized in Table 1 . The highest yield of $4.58 \%$ was obtained from the ultrasonic extraction (USE) method. This result was in concordance with that reported by Hemwimol et al [27] for the extraction of anthraquinones from the roots of $M$. citrifolia using the ultrasonic-assisted ethanol extraction method. Compared with that of the non-sonicated sample, the extraction time was significantly reduced by $75 \%$ using the sonicated sample. Sun et al [28] reported that the yield of ultrasonically extracted pectin markedly improved in comparison with the conventional method. This could be explained by the fact that cavitation from ultrasound waves could break down the cell wall, thus allowing the solvent to access the intracellular content, releasing the target compound, and diffusing to the solvent [29]. Therefore, this method has been applied to natural product component extraction processes.

Moreover, Zhang [30] reported that the proficient frequency of ultrasound ranges from 20 to $50 \mathrm{kHz}$; however, the yield of the crude extracts from Rlc. Haw Yuan Beauty extracted by SE was significantly improved compared to that extracted by the SFE method. This might be because of the combination of the mechanical effects and extraction time in the SE method, which substantially promotes solvent penetration into the cell [31]. Additionally, the SFE method produced the lowest yield (1.36\%) with a short duration of extraction and high temperature used. Thus, time and temperature are crucial factors in extraction as long extraction periods enhance the extraction yields [32]. Moreover, the 3 crude extracts obtained via different extraction methods showed similar visual appearance, solidity, stickiness, and magenta color.

\section{Quantitative analysis of the total flavonoid and cyanidin-3-O-glucoside contents}

The results showed that the total flavonoid content varied remarkably with the different extraction methods (Table 1). The SE method could be considered advantageous because of the highest flavonoid content $(8.45 \mathrm{mg} \mathrm{QE} / \mathrm{g}$ extract). The flavonoid content of the extract from USE and SFE were 7.01 and $6.68 \mathrm{mg} \mathrm{QE} / \mathrm{g}$ extract, respectively. The SFE method may have reduced the total flavonoid recovery because of the high extraction temperature. Flavanoids are thermally sensitive and can easily be 
degraded; according to Marszałek et al [33], they are generally susceptible to thermal degradation in the range of $35-65^{\circ} \mathrm{C}$ with pressure higher than $100 \mathrm{MPa}$ during the extraction process. Moreover, the stability of flavonoids is dependent on several factors including $\mathrm{pH}$, time, temperature, and the time/temperature combination [34].

Cyanidin-3-O-glucoside has been found in orchid flowers. According to Duan et al [35], cyanidin-3-O-glucoside from Chinese bayberry was hydrolyzed to cyanidin during extraction process. For all extraction methods, cyanidin-3-O-glucoside was the main flavonoid in Rlc. Haw Yuan Beauty. The results showed that SFE resulted in the highest cyanidin-3-O-glucoside content (43599.77 $\mu \mathrm{g} / \mathrm{g}$ extract) (Table 1). This could be because carbonic acid produced by the solubilization of $\mathrm{CO}_{2}$ reduced the $\mathrm{pH}$ of the water, resulting in more flavylium cations in cyanidin-3-O-glucoside. Thus, their hydrophilic property was increased which promoted the solubility of cyanidin-3-O-glucoside in ethanol $[36,37]$.

\section{Phenolic profile of the extracts}

The total phenolic content obtained from SE, USE, and SFE was 69.34, 45.23, and $41.11 \mathrm{mg} \mathrm{GAE} / \mathrm{g}$ extract, respectively (data not shown). The phenolic compounds identified included chlorogenic acid, caffeic acid, myricetin, luteolin, kaempferol, and apigenin (Table 2). Chlorogenic acid was the primary phenolic compound (8042.91 $\mu \mathrm{g} / \mathrm{g}$ extract) obtained from the SFE method, which had the lowest extraction yield. The results suggested that the SFE extraction method enhanced the efficiency of the extraction to obtain a higher concentration of chlorogenic acid. Other phenolic compounds such as caffeic acid, myricetin, luteolin, kaempferol, and apigenin were also found using the SE, USE, and SFE methods at low levels. According to Cvetanović et al [38], the optimal temperature for apigenin, luteolin, and kaempferol extraction was $115^{\circ} \mathrm{C}$. However, apigenin was found in USE and SFE owing to its structural differences, and it influenced the solubility of the phenolic compounds.

\section{Antioxidant activity}

In this study, the results of the $\mathrm{DPPH}^{\bullet}$ and $\mathrm{ABTS}^{\bullet+}$ assays were expressed as the $\mathrm{IC}_{50}$ values, representing the concentration of the extract necessary to decrease the initial absorbance of the $\mathrm{DPPH}^{\circ}$ solution by $50 \%$; lower $\mathrm{IC}_{50}$ values are associated with higher DPPH ${ }^{\bullet}$ radical scavenging activity [39]. The relationship between the extraction method and the antioxidant activity was studied using different

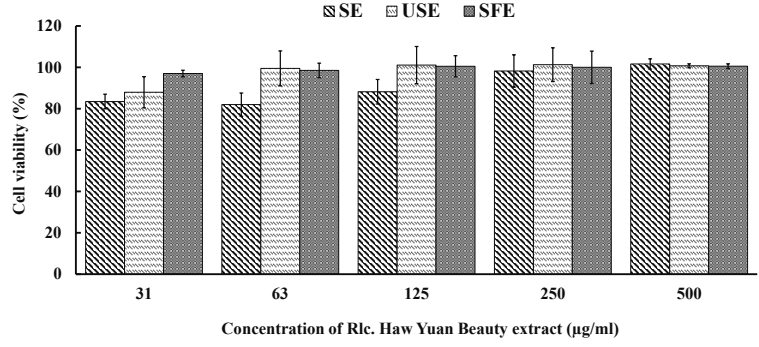

Fig. 1 Cytotoxic properties $(\mu \mathrm{g} / \mathrm{ml})$ of the crude extracts from Rlc. Haw Yuan Beauty obtained from different extraction methods. Error bars represent \pm SD of 3 replicates.

extraction methods; these were based on different mechanisms and compared with Trolox and Lascorbic acid (Table 3). The maximum antioxidant activity was found in the crude extract obtained using the SE method. The $\mathrm{IC}_{50}$ values of the extracts obtained by SE, USE, and SFE were 0.19 , 0.21 , and $0.26 \mathrm{mg} / \mathrm{ml}$, respectively. The value from the SE method was lower than that of the synthetic antioxidant L-ascorbic acid at $0.24 \mathrm{mg} / \mathrm{ml}$. The result was correlated with the phenolic and flavonoid content owing to the existence of an orthodihydroxy structure in the B ring of phenolic compounds, making them effective hydrogen donors. There is a positive correlation between bioactive compounds in the crude extracts and the level of antioxidant activity [40]. It seems that this positive correlation between the antioxidant activity and phenolic content is related to the presence of $-\mathrm{OH}$ moieties, which are potent $\mathrm{H}$ donors [41]. A slightly different value was observed for $\mathrm{ABTS}^{\bullet+}$ radical scavenging. The crude extracts became more active towards $\mathrm{ABTS}^{\bullet+}$ radicals with the $\mathrm{IC}_{50}$ values of $0.10,0.11$, and $0.13 \mathrm{mg} / \mathrm{ml}$ in SE, USE, and SFE, respectively. However, the antioxidant capacity of the crude extracts from all extraction methods in the $\mathrm{ABTS}^{\bullet+}$ assay was lower than that of the Lascorbic acid. Ethanol as a solvent used in all extraction methods showed the highest ability to extract potential antioxidant-like metabolites. Metabolites with antioxidant properties inhibit the oxidation of other molecules, thereby protecting these molecules against possible damages caused by reactive oxygen species.

\section{Cytotoxicity}

Human skin fibroblasts (CCD-986SK) were treated with the crude extracts at varying concentrations (31 to $500 \mu \mathrm{g} / \mathrm{ml}$ ). The results showed that the crude extracts from the different extraction methods 
Table 2 Phenolic compounds in the crude extracts from Rlc. Haw Yuan Beauty.

\begin{tabular}{|c|c|c|c|c|c|c|c|}
\hline \multirow{2}{*}{$\begin{array}{l}\text { Extraction } \\
\text { method }\end{array}$} & \multicolumn{7}{|c|}{ Phenolic compound ( $\mu \mathrm{g} / \mathrm{g}$ extract) } \\
\hline & Gallic acid & Chlorogenic acid & Caffeic acid & Myricetin & Luteolin & Kaempferol & Apigenin \\
\hline SE & $11053.81 \pm 15.38^{\mathrm{a}}$ & $6632.52 \pm 12.44^{b}$ & $203.36 \pm 2.42^{\mathrm{a}}$ & $567.90 \pm 12.93^{\mathrm{b}}$ & $92.77 \pm 1.00^{\mathrm{b}}$ & $64.27 \pm 1.41^{\mathrm{b}}$ & ND \\
\hline USE & $8660.00 \pm 14.65^{b}$ & $4890.00 \pm 11.53^{c}$ & $130.00 \pm 1.90^{\mathrm{b}}$ & $660.00 \pm 7.20^{\mathrm{a}}$ & $100.00 \pm 1.49^{\mathrm{a}}$ & $100.00 \pm 1.96^{\mathrm{a}}$ & $28 \pm 1.20^{\mathrm{a}}$ \\
\hline SFE & $2021.90 \pm 5.98^{\mathrm{c}}$ & $8042.91 \pm 12.14^{\mathrm{a}}$ & $86.42 \pm 1.77^{\mathrm{c}}$ & $383.92 \pm 8.76^{\mathrm{c}}$ & $78.14 \pm 1.09^{c}$ & $58.63 \pm 2.04^{c}$ & $28 \pm 1.22^{\mathrm{a}}$ \\
\hline
\end{tabular}

Table 3 Antioxidant activities of the crude extracts from Rlc. Haw Yuan Beauty.

\begin{tabular}{lcr}
\hline \multirow{2}{*}{ Extraction method } & \multicolumn{2}{c}{$\mathrm{IC}_{50}(\mathrm{mg} / \mathrm{ml})$} \\
\cline { 2 - 3 } & $\mathrm{DPPH}^{\bullet}$ & $\mathrm{ABTS}^{\bullet+}$ \\
\hline SE & $0.19 \pm 0.003^{\mathrm{d}}$ & $0.10 \pm 0.001^{\mathrm{b}}$ \\
USE & $0.21 \pm 0.002^{\mathrm{c}}$ & $0.11 \pm 0.002^{\mathrm{b}}$ \\
SFE & $0.26 \pm 0.006^{\mathrm{a}}$ & $0.13 \pm 0.008^{\mathrm{a}}$ \\
Trolox & $0.02 \pm 0.001^{\mathrm{e}}$ & $0.01 \pm 0.007^{\mathrm{d}}$ \\
L-ascorbic acid $^{*}$ & $0.24 \pm 0.001^{\mathrm{b}}$ & $0.03 \pm 0.002^{\mathrm{c}}$ \\
\hline a,b,c Different letters represent significant difference $(p<0.05)$. \\
\multicolumn{2}{c}{ Values are expressed as mean $\pm \mathrm{SD}(N=3)}$. \\
* Trolox and L-ascorbic acid were used as positive control.
\end{tabular}

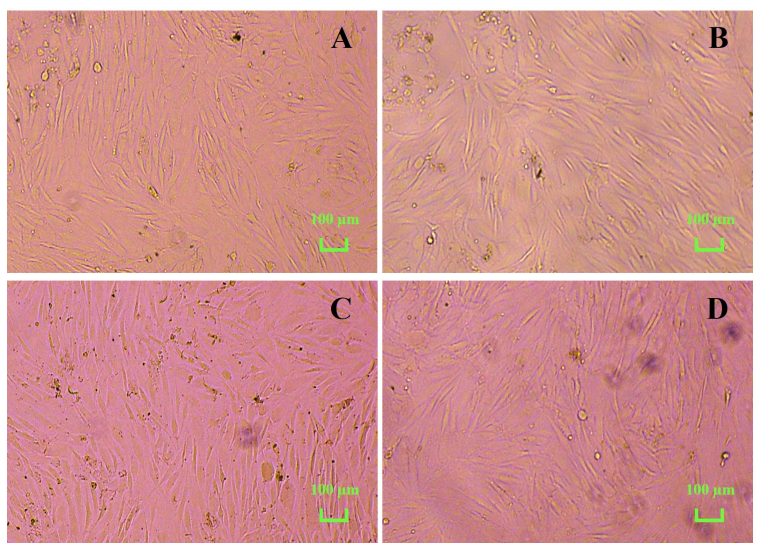

Fig. 2 Morphology of human skin normal cells ATCC no. CRL 1947 (CCD-986SK). (A) untreated cells (DMSO-treated); (B) cells treated with SE; (C) cells treated with USE; and (D) cells treated with SFE, at $500 \mu \mathrm{g} / \mathrm{ml}$. Cell morphology was monitored using inverted fluorescence microscope (Olympus IX71). All images were magnified 4X, and the scale bar was $100 \mu \mathrm{m}$.

exhibited considerable dose-dependent inhibition of cell growth (Fig. 1). Crude extract from the SE method was the most cytotoxic to CCD-986SK fibroblasts; indeed, the SE extract showed the highest percentage of dead cells because of high levels of phenolic and flavonoid compounds. The results showed that the crude extract from the SE method affected CCD-986SK fibroblast cell viability even at low concentrations. This indicates the presence of some cytotoxic compounds in these extracts.
Table 4 Anti-aging enzyme activities of the crude extracts from Rlc. Haw Yuan Beauty.

\begin{tabular}{lccc}
\hline Extraction & Anti-elastase & \multicolumn{2}{c}{ Anti-collagenase activity (\%) } \\
\cline { 3 - 4 } method & activity (\%) & MMP-1 & MMP-2 \\
\hline SE & $89.12 \pm 0.01^{\mathrm{b}}$ & $90.06 \pm 0.05^{\mathrm{b}}$ & $90.36 \pm 0.08^{\mathrm{b}}$ \\
USE & $88.19 \pm 0.13^{\mathrm{c}}$ & $89.40 \pm 0.17^{\mathrm{c}}$ & $89.94 \pm 0.04^{\mathrm{c}}$ \\
SFE & $88.08 \pm 0.07^{\mathrm{c}}$ & $89.03 \pm 0.06^{\mathrm{d}}$ & $89.13 \pm 0.02^{\mathrm{d}}$ \\
EGCG $^{*}$ & $90.98 \pm 0.01^{\mathrm{a}}$ & $91.98 \pm 0.0^{\mathrm{a}}$ & $91.42 \pm 0.02^{\mathrm{a}}$ \\
\hline \multicolumn{3}{c}{$\mathrm{a}, \mathrm{b}, \mathrm{c}$} & Different letters represent significant difference $(p<0.05)$. \\
\multicolumn{3}{c}{ Values are expressed as mean $\pm \mathrm{SD}(N=3)}$. \\
* Positive control.
\end{tabular}

The highest quantity of bioactive phytoconstituents, flavonoids, and phenolics was present in the extract obtained from the SE method, which may be responsible for the radical-scavenging activity and toxicity [42]. The viability of CCD-986SK fibroblasts was over $90 \%$ higher in the crude extract from the SFE method compared to those from the SE and USE methods at $31 \mu \mathrm{g} / \mathrm{ml}$. In addition, the CCD986SK fibroblast cell morphology was monitored using inverted fluorescence microscope (Fig. 2). Cells $72 \mathrm{~h}$ post-exposure to $500 \mu \mathrm{g} / \mathrm{ml}$ crude extract were compared with DMSO treated cells. This revealed that crude extracts from SE, USE, and SFE were toxic within acceptable limit (cell viability $>80 \%$ ) $[43,44]$ and did not affect cell growth. Therefore, cells could be grown continuously under extract treatment conditions.

\section{Collagenase inhibitory activity}

Collagenase inhibitory activity was determined by analyzing the inhibition of MMP-1 and MMP-2. Collagen is the most abundant extracellular matrix protein in dermal fibroblasts. It plays a key role in regulating the tensile strength of the skin and connective tissue and in cell division and differentiation $[45,46]$. The inhibitory activities of crude extracts from Rlc. Haw Yuan Beauty against MMP1 and MMP-2 are shown in Table 4. All of the crude extracts from the different extraction methods (SE, USE, and SFE) exhibited significant inhibitory effects on MMP-1 and MMP- 2 at greater than $80 \%$. The crude extracts from SE and SFE showed the 
highest and lowest MMP-1 and MMP-2 inhibitory activities, respectively. Additionally, all crude extracts showed significant differences compared to EGCG. Collagenases (MMP-1, MMP-8, and MMP-13) and gelatinases (MMP-2 and MMP-9) break down skin collagen, contributing to aging and wrinkling. Over $90 \%$ of the collagen in the human body is type I, and MMP-1 is a collagenase that specifically degrades type I collagen. MMP2 is commonly known as gelatinase, which has the potential to degrade both collagen and elastin fiber networks. The crude extracts from Rlc. Haw Yuan Beauty contain bioactive compounds such as flavonoids and phenolic compounds which possess enzyme inhibitory activities, possibly resulting from the hydroxyl group attached to the benzene moiety in the polyphenol structure. The compound acts as a hydrogen acceptor or donor to the functional group of the enzyme. This interaction changes the enzyme conformation, which could lead to denaturation. This possibly leads to prolonged skin damage, as collagenase cleaves the peptide bond and breaks down the collagen.

\section{Elastase inhibitory activity}

Elastase is a proteolytic enzyme that causes degradation of elastin in the extracellular matrix and results in skin aging (sagging and wrinkles). The assay was performed using $N$-succinyl-Ala-Ala-Ala$p$-nitroanilide as the substrate. The results of the elastase inhibition test are shown in Table 4. Crude extract from SE showed lower elastase inhibition compared with EGCG. It can be proposed here that the hydroxyl group in the phenolic compound interacts with the carboxyl group in the elastase active site. Therefore, the enzyme was inhibited which increased skin elasticity and decreased wrinkle formation. However, elastase inhibition by the crude extract obtained with SE had the highest activity, which was related to antioxidant activity as observed with the DPPH and ABTS analyses. Among phenolic compounds, gallic acid could be an effective anti-aging agent by affecting human fibroblasts in wound healing [47]. The anti-elastase properties could be a result of highly polar compounds that are not extracted using the SFE method. Furthermore, the elastase inhibitory activity of the crude extracts from SE, USE, and SFE was significantly different $(p<0.05)$ when compared with that of EGCG.

\section{CONCLUSION}

Solvent extraction (SE) displayed high efficiency in extracting bioactive compounds including flavonoids and gallic acid. Cyanidin-3-O-glucoside and chlorogenic acid were the major compounds observed in crude extracts from supercritical fluid extraction. The crude extract from SE showed the lowest $\mathrm{IC}_{50}$ values for $\mathrm{DPPH}^{\bullet}$ and $\mathrm{ABTS}^{\bullet+}$ assays. In addition, these crude extracts were also non-toxic to normal CCD-986SK cells in a dose-dependent manner. Moreover, remarkable collagenase and elastase inhibitory activities were observed in crude extracts from the different extraction methods.

Acknowledgements: This work was supported by Thailand's national budget for research (National Research Council of Thailand) and Research and Development Institute of Suan Dusit University. We thank Agriculture and Functional Food Processing, Pilot Plant Development and Training Institute, King Mongkut's University of Technology Thonburi (Bangkhuntein Campus) for scientific instrument facilities.

\section{REFERENCES}

1. Albert NW, Arathoon S, Collette VE, Schwinn KE, Jameson PE, Lewis DH, et al (2010) Activation of anthocyanin synthesis in Cymbidium orchids: variability between known regulators. Plant Cell Tissue Organ Cult 100, 355-360.

2. Dillard CJ, German JB (2000) Phytochemicals: nutraceuticals and human health. J Sci Food Agric 80, 1744-1756.

3. Chen Y, Zhang H, Wang Y, Nie S, Li C, Xie M (2014) Acetylation and carboxymethylation of the polysaccharide from Ganoderma atrum and their antioxidant and immunomodulating activities. Food Chem 156, 279-288.

4. Li BJ, Zheng BQ, Wang JY, Tsai WC, Lu HC, Zou LH, Wang Y (2020) New insight into the molecular mechanism of colour differentiation among floral segments in orchids. Commun Biol 3, ID 89.

5. Paudel MR, Chand MB, Pant B, Pant B (2019) Assessment of antioxidant and cytotoxic activities of extracts of Dendrobium crepidatum. Biomolecules 9 , ID 478.

6. Bakhtiary F, Sayevand HR, Khaneghah AM, Haslberger AG, Hosseini H (2018) Antibacterial efficacy of essential oils and sodium nitrite in vacuum processed beef fillet. Appl Food Biotechnol 5, $1-10$.

7. Tadokoro T, Bonte F, Archambault JC, Cauchard JH, Neveu M, Ozawa K, Shinn S (2010) Whitening efficacy of plant extracts including orchid extracts on Japanese female skin with melasma and lentigo senilis. J Dermatol 37, 522-530.

8. Hadi H, Razali SNS, Awadh AI (2015) A comprehensive review of the cosmeceutical benefits of Vanda species (Orchidaceae). Nat Prod Commun 10, 1483-1488. 
9. Dai Y, Witkamp GJ, Verpoorte R, Choi YH (2013) Natural deep eutectic solvents as a new extraction media for phenolic metabolites in Carthamus tinctorius L. Anal Chem 85, 6272-6278.

10. Nakbanpote W, Ruttanakorn M, Sukadeetad K, Sakkayawong N, Damrianant S (2019) Effects of drying and extraction methods on phenolic compounds and in vitro assays of Eclipta prostrata Linn leaf extracts. ScienceAsia 45, 127-137.

11. Kuppusamy P, Yusoff MM, Parine NR, Govindan $\mathrm{N}$ (2015) Evaluation of in vitro antioxidant and antibacterial properties of Commelina nudiflora Lextracts prepared by different polar solvents. Saudi J Biol Sci 22, 293-301.

12. Bazzicalupo M, Burlando B, Denaro M, Barreca D, Trombetta D, Smeriglio A, Cornara L (2019) Polyphenol characterization and skin-preserving properties of hydroalcoholic flower extract from Himantoglossum robertianum (Orchidaceae). Plants 8, ID 502.

13. Jeong KM, Yang M, Jin Y, Kim EM, Ko J, Lee J (2017) Identification of major flavone C-glycosides and their optimized extraction from Cymbidium kanran using deep eutectic solvents. Molecules 22, ID 2006.

14. Santos MC, Koetz M, Mendez AS, Henriques AT (2020) Ultrasound-assisted extraction optimization and validation of ultra-performance liquid chromatographic method for the quantification of miquelianin in Cuphea glutinosa leaves. Talanta 216, ID 120988.

15. Attard TM, Bukhanko N, Eriksson D, Arshadi M, Geladi P, Bergsten U, Budarin VL, Clark JH, et al (2018) Supercritical extraction of waxes and lipids from biomass: A valuable first step towards an integrated biorefinery. J Clean Prod 177, 684-698.

16. Giménez-Rota C, Langa E, Urieta JS, Hernáiz MJ, Mainar AM (2020) Supercritical antisolvent fractionation of antioxidant compounds from Lavandula luisieri (Rozeira) Riv.-Mart. J Supercrit Fluids 161, ID 104821.

17. Nagananda GS, Rajath S, Shankar PA, Rajani ML (2013) Phytochemical evaluation and in vitro free radical scavenging activity of successive whole plant extract of orchid Cottonia peduncularis. Res Art Biol Sci 3, ID 91.

18. Molnar M, Mendešević N, Šubarić D, Banjari I, Jokić $S$ (2017) Comparison of various techniques for the extraction of umbelliferone and herniarin in Matricaria chamomilla processing fractions. Chem Cent $J$ 11, ID 78.

19. Wang J, Sun B, Cao Y, Tian Y, Li X (2008) Optimisation of ultrasound-assisted extraction of phenolic compounds from wheat bran. Food Chem 106, 804-810.

20. Kazan A, Koyu H, Turu IC, Yesil-Celiktas O (2014) Supercritical fluid extraction of Prunus persica leaves and utilization possibilities as a source of phenolic compounds. J Supercrit Fluids 92, 55-59.

21. Ghasemzadeh A, Jaafar HZ, Rahmat A, Ashkani S
(2015) Secondary metabolites constituents and antioxidant, anticancer and antibacterial activities of Etlingera elatior (Jack) RM Sm grown in different locations of Malaysia. BMC Complementary Altern Med 15, ID 335.

22. Brand-Williams W, Cuvelier ME, Berset CLWT (1995) Use of a free radical method to evaluate antioxidant activity. LWT Food Sci Technol 28, 25-30.

23. Cai Y, Luo Q, Sun M, Corke H (2004) Antioxidant activity and phenolic compounds of 112 traditional Chinese medicinal plants associated with anticancer. Life Sci 74, 2157-2184.

24. Netchareonsirisuk P, Puthong S, Dubas S, Palaga T, Komolpis K (2016) Effect of capping agents on the cytotoxicity of silver nanoparticles in human normal and cancer skin cell lines. J Nanopart Res 18, ID 322.

25. Pientaweeratch S, Panapisal V, Tansirikongkol A (2016) Antioxidant, anti-collagenase and antielastase activities of Phyllanthus emblica, Manilkara zapota and silymarin: An in vitro comparative study for anti-aging applications. Pharm Biol 54, 1865-1872.

26. Kim YJ, Uyama H, Kobayashi S (2004) Inhibition effects of (+)-catechin-aldehyde polycondensates on proteinases causing proteolytic degradation of extracellular matrix. Biochem Biophys Res Commun 320, 256-261.

27. Hemwimol S, Pavasant P, Shotipruk A (2006) Ultrasound-assisted extraction of anthraquinones from roots of Morinda citrifolia. Ultrason Sonochem 13, 543-548.

28. Sun Y, Liu D, Chen J, Ye X, Yu D (2011) Effects of different factors of ultrasound treatment on the extraction yield of the all-trans- $\beta$-carotene from citrus peels. Ultrason Sonochem 18, 243-249.

29. Zhang QW, Lin LG, Ye WC (2018) Techniques for extraction and isolation of natural products: A comprehensive review. Chin Med 13, ID 20.

30. Zhang Y (2018) Chaotic oscillations of gas bubbles under dual-frequency acoustic excitation. Ultrason Sonochem 40, 151-157.

31. Dent M, Dragović-Uzelac V, Penić M, Bosiljkov T, Levaj B (2013) The effect of extraction solvents, temperature and time on the composition and mass fraction of polyphenols in Dalmatian wild sage (Salvia officinalis L.) extracts. Food Sci Biotechnol 51, 84-91.

32. Spigno G, Tramelli L, De Faveri DM (2007) Effects of extraction time, temperature and solvent on concentration and antioxidant activity of grape marc phenolics. J Food Eng 81, 200-208.

33. Marszałek K, Woźniak Ł, Kruszewski B, Skąpska S (2017) The effect of high-pressure techniques on the stability of anthocyanins in fruit and vegetables. Int $J$ Mol Sci 18, ID 277.

34. Amr A, Tamini EA (2007) Stability of the crude extracts of Ranunculus asiaticus anthocyanins and their use as food colorants. Int J Food Sci Technol 42, 
985-991.

35. Duan W, Jin S, Zhao G, Sun P (2015) Microwaveassisted extraction of anthocyanin from Chinese bayberry and its effects on anthocyanin stability. Food Sci Technol Int 35, 524-530.

36. Paes J, Dotta R, Barbero GF, Martínez J (2014) Extraction of phenolic compounds and anthocyanins from blueberry (Vaccinium myrtillus L.) residues using supercritical $\mathrm{CO}_{2}$ and pressurized liquids. $J \mathrm{Su}$ percrit Fluids 95, 8-16.

37. Kühn S, Temelli F (2017) Recovery of bioactive compounds from cranberry pomace using ternary mixtures of $\mathrm{CO}_{2}+$ ethanol + water. $J$ Supercrit Fluids 130, 147-155.

38. Cvetanović A, Švarc-Gajić J, Zeković Z, Jerković J, Zengin G, Gašić U, Tešić Ž, Mašković P, et al (2019) The influence of the extraction temperature on polyphenolic profiles and bioactivity of chamomile (Matricaria chamomilla L.) subcritical water extracts. Food Chem 271, 328-337.

39. Li X, Wu X, Huang L (2009) Correlation between antioxidant activities and phenolic contents of Radix Angelicae Sinensis (Danggui). Molecules 14, 5349-5361.

40. Gris EF, Mattivi F, Ferreira EA, Vrhovsek U, Filho DW, Pedrosa RC, Bordignon-Luiz MT (2011) Stilbenes and tyrosol as target compounds in the assessment of antioxidant and hypolipidemic activity of Vitis vinifera red wines from Southern Brazil. J Agric Food Chem 59, 7954-7961.
41. Taghizadeh SF, Rezaee R, Davarynejad G, Karimi G, Nemati SH, Asili J (2018) Phenolic profile and antioxidant activity of Pistacia vera var. Sarakhs hull and kernel extracts: the influence of different solvents. J Food Meas Charact 12, 2138-2144.

42. El-Baz FK, Hassan AZ, Abd-Alla HI, Aly HF, Mahmoud K (2017) Phytochemical analysis, assessment of antiproliferative and free radical scavenging activity of Morus alba and Morus rubra fruits. Phytochem Anal 10, 189-199.

43. López-García J, Lehocký M, Humpolíček P, Sáha P (2014) HaCaT keratinocytes response on antimicrobial atelocollagen substrates: extent of cytotoxicity, cell viability and proliferation. J Funct Biomater 5, 43-57.

44. ISO (2009) Biological Evaluation of Medical Devices, Part 5: Tests for In Vitro Cytotoxicity, International Organization for Standardization, Geneva, Switzerland.

45. Giacomoni PU, Rein G (2001) Factors of skin ageing share common mechanisms. Biogerontology 2, 219-229.

46. Tracy LE, Minasian RA, Caterson EJ (2016) Extracellular matrix and dermal fibroblast function in the healing wound. Adv Wound Care 5, 119-136.

47. Yang L, Zheng Z, Zhou Q, Bai X, Fan L, Yang C, Su L, Hu D (2017) miR-155 promotes cutaneous wound healing through enhanced keratinocytes migration by MMP-2. J Mol Histol 48, 147-155. 